\title{
Metachronous colon cancer risk following surgery for first primary rectal cancer in Lynch syndrome
}

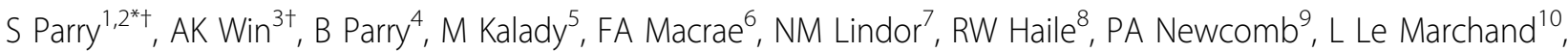 \\ $S$ Gallinger ${ }^{11,12}$, JL Hopper ${ }^{3}$, MA Jenkins ${ }^{3}$, Colon Cancer Family Registry \\ From Familial Aspects of Cancer 2011 Research and Practice: A combined meeting of kConFab, Australian \\ Breast Cancer Family Study, Australian Colorectal Cancer Family Study, Australian Ovarian Cancer Study, \\ Family Cancer Clinics of Australia and New Zealand and kConFab \\ Kingscliff, Australia. 23-26 August 2011
}

\section{Background}

It is known that metachronous colorectal cancer risk for Lynch syndrome patients with primary colon cancer is high and total colectomy is the preferred option [1]. However if the index primary cancer is in the rectum, management advice is complicated by considerations of worsening bowel function or stoma formation. To aid surgical decision-making, we estimated the risk of metachronous colon cancer for Lynch syndrome patients who underwent either anterior resection or abdominoperineal resection for primary rectal cancer.

\section{Methods}

This retrospective cohort study comprised 79 MMR gene mutation carriers (18 MLH1, 55 MSH2, 4 MSH6 and 2 PMS2) from the Colon Cancer Family Registry who had a surgical resection for their first primary rectal cancer. Age-dependent cumulative risks of metachronous colon cancer were calculated using the KaplanMeier method. Risk factors for metachronous colon cancer were assessed using a Cox proportional hazards regression.

\section{Results}

During 866 person-years of observation (median 9 years; range 1-32 years) since diagnosis of first rectal cancer, a total of $21(27 \%)$ carriers were diagnosed with metachronous colon cancer (incidence 24.2; 95\% CI 15.837.2 per 1000 person-years). Incidence for carriers who had an anterior resection (26.8; 95\% CI 15.5-46.1 per

\footnotetext{
† Contributed equally

${ }^{1}$ New Zealand Familial Gastrointestinal Cancer Registry, Auckland City Hospital, New Zealand

Full list of author information is available at the end of the article
}

1000 person-years) was not different from that for carriers who had an abdominoperineal resection (21.0; 95\% CI $10.5-42.1$ per 1000 person-years) $(P=0.1)$. Cumulative risk of metachronous colon cancer was 19\% (95\% CI $9-31 \%)$ at 10 years, $47 \%(95 \%$ CI $31-68 \%)$ at 20 years and $69 \%$ (95\% CI $45-89 \%)$ at 30 years after surgical resection. There was no difference in the frequency of surveillance colonoscopy between two types of surgery (one colonoscopy per 1.1 (95\% CI $0.9-1.2)$ years after anterior resection vs. one colonoscopy per $1.4(95 \%$ CI 1.0-1.8) years after abdominoperineal resection).

\section{Conclusions}

For carriers of MMR gene mutations who contract rectal cancer, the metachronous cancer risk is substantial and mirrors that seen for carriers undergoing segmental resection for primary colon cancer [1], despite the majority continuing to receive frequent surveillance colonoscopy. This risk needs to be considered when the extent of surgery for primary rectal cancer is planned. Whereas total colectomy for primary colon cancer in mutation carriers is appropriate, for primary rectal cases this strategy has major implications for continence and need for stoma. Nevertheless, given the high metachronous risk, this needs serious consideration especially for younger patients.

\footnotetext{
Author details

${ }^{1}$ New Zealand Familial Gastrointestinal Cancer Registry, Auckland City Hospital, New Zealand. ${ }^{2}$ Department of Gastroenterology, Middlemore Hospital, Auckland, New Zealand. ${ }^{3}$ Centre for Molecular, Environmental, Genetic and Analytic Epidemiology, The University of Melbourne, Parkville, Victoria, Australia. ${ }^{4}$ Colorectal Surgical Unit, Auckland City Hospital, New Zealand. ${ }^{5}$ Department of Colorectal Surgery, Digestive Disease Institute, Cleveland Clinic, Cleveland, Ohio, USA. ${ }^{6}$ Colorectal Medicine and Genetics,
} 
The Royal Melbourne Hospital, Parkville, Victoria, Australia. ${ }^{7}$ Department of Medical Genetics, Mayo Clinic, Rochester, Minnesota, USA. ${ }^{8}$ Department of Preventive Medicine, University of Southern California, Los Angeles, California, USA. ${ }^{9}$ Cancer Prevention Program, Fred Hutchinson Cancer Research Center, Seattle, Washington, USA. ${ }^{10}$ University of Hawaii Cancer Center, Honolulu, Hawaii, USA. ${ }^{11}$ Samuel Lunenfeld Research Institute, Mount Sinai Hospital, Toronto, Ontario, Canada. ${ }^{12}$ Cancer Care Ontario, Toronto, Ontario, Canada.

Published: 12 April 2012

\section{Reference}

1. Parry S, Win AK, Parry B, Macrae FA, Gurrin LC, Church JM, Baron JA, Giles GG, Leggett BA, Winship I, et al: Metachronous colorectal cancer risk for mismatch repair gene mutation carriers: the advantage of more extensive colon surgery. Gut 2011, 60:950-957.

doi:10.1186/1897-4287-10-S2-A74

Cite this article as: Parry et al:: Metachronous colon cancer risk following surgery for first primary rectal cancer in Lynch syndrome. Hereditary Cancer in Clinical Practice 2012 10(Suppl 2):A74.

\section{Submit your next manuscript to BioMed Central} and take full advantage of:

- Convenient online submission

- Thorough peer review

- No space constraints or color figure charges

- Immediate publication on acceptance

- Inclusion in PubMed, CAS, Scopus and Google Scholar

- Research which is freely available for redistribution

Submit your manuscript at www.biomedcentral.com/submit 